\title{
Особливості пероксидного окиснення ліпідів та антиоксидантного захисту у тканині міокарда при політравмі (експериментальні дослідження)
}

\author{
Д. В. Козак
}

ДВНЗ «Тернопільський державний медичний університет імені І. Я. Горбачевського МОЗ України», Тернопіль, Україна

Резюме. Проблема травматизма достаточно актуальна во всех видах спорта, особенно в юношеском возрасте. Спортсмены молодого возраста, стараясь как можно быстрее добиться высоких результатов, недостаточно прорабатывают и совершенствуют технику двигательной активности, пренебрегают принципами постепенного увеличения нагрузок, оптимизации соотношения объема и интенсивности нагрузок. Вместе с тем, органы и системы не всегда успевают подготовиться к повышенным условиям для достижения высоких целей, это касается костно-мышечной системы и особенно изменения структурных компонентов сердечно-сосудистой системы, которые остро реагируют на воздействия внешних факторов стрессового генеза.

В ткани миокарда под влиянием скелетной травмы уже через 2 часа существенно возрастает, по сравнению с контрольной группой, содержание ТБК-активных продуктов перикисного окисления липидов и остается повышенным до 28 суток посттравматического периода. Наибольшая интенсификация липопероксидации и истощения антиоксидантной защиты наступает через трое суток после нанесения травмы.

Ключевые слова: скелетная травма, миокард, пеороксидное окисление липидов, супероксиддисмутаза, каталаза.

Summary: The problem of traumatism is quite acute by all sports, especially during adolescence. Young athletes, trying to achieve high results as soon as possible, work out and improve the technique of motor activity not enough, ignore the principles of gradual increase of loads, optimization of the volume and intensity of stress. However, organs and systems do not always have time to get ready to elevated conditions to achieve high goals, especially concerning the musculoskeletal system especially the changes in the structural components of of the cardiovascular system reacts on external factors of stress origin [1].

The significantly increases of TBA-active products of lipid peroxidation content in myocardial tissue, under the influence of skeletal trauma in 2 hours, compared with the control group. It's remained elevated up to 28 days post traumatic period. The greatest intensification of lipid peroxidation and antioxidant depletion occurs within 3 days after causing of injury.

Key words: skeletal trauma, myocardium, lipid peroxidation, superoxide dismutase, catalase.

Постановка проблеми. Сучасний професійний спорт з інтенсивними та підвищеними навантаженнями на організм спортсмена висуває значні вимоги і тим самим підвищує ризик отримання травми. У різних країнах світу кількість травм у спорті становить 10-17 \% всіх пошкоджень. Найчастіше травмуються спортсмени в ігрових видах спорту (забої, розтягнення м'язів і сухожиль, переломи тощо) Усі травми в гімнастиці належать до категорії гострих. Домінують переломи нижніх і верхніх кінцівок та хребта [2]. В Україні теж відмічається невпинна тенденція до росту частоти спортивної травми, що становить понад 3,7 на 10 тис. населення [3]. 
У патогенезі тяжкої скелетної травми останніми роками домінує концепція травматичної хвороби, як порушення життєдіяльності організму, що виникає в результаті дії надмірного механічного агента (пошкодження) і виявляється складним комплексом взаємозв'язаних розладів фрункцій, неоднакових у різні ії̈ періоди, сукупністю адаптивних (пристосувальних) реакцій, спрямованих на збереження життя індивіда, відновлення порушених фрункцій і структур [4]. Сукупність системних відхилень, які виникають після тяжкої скелетної травми, не можуть не торкатися функціонального стану міокарда - основного лімітуючого органа киснево-транспортної системи організму [5].

Серед багатьох чинників ураження міокарда в умовах скелетної травми важливе місце відводиться пероксидному окисненню ліпідів (ПОЛ). Після травми активація процесів ліпопероксидації має адаптивний характер, сприяючи трансмембранному обміну [6]. Однак при тяжкій травмі цей процес стає неконтрольованим через виснаження антиоксидантного захисту і з часом досягає найбільшої інтенсивності розвитку системної відповіді організму на запалення [7]. Це сприяє розвитку системної мембранопатії і поліорганної недостатності.

У наших попередніх роботах було показано, що інтенсивність ПОЛ та реакція антиоксидантної системи при тяжкій скелетній травмі має коливальний характер з періодами підйому та спаду активності [8]. Однак ці процеси у тканині міокарда вивчені недостатньо.

Цілі, завдання роботи, матеріали і методи. Завданням даної роботи $\epsilon$ вивчення в динаміці гострого періоду та періодів ранніх і пізніх проявів політравми - антиоксидантно-прооксидантного балансу тканини міокарда.

Експерименти проведено на 62 нелінійних білих щурах-самцях масою 180-200 г, які утри- мувалися на стандартному раціоні віварію. Політравму моделювали в умовах тіопенталонатрієвого наркозу $\left(40 \mathrm{Mr} \cdot \mathrm{K}^{-1}\right) .3$ експерименту тварин виводили після наркотизації шляхом тотального кровопускання із серця через дві години, 1-, 3-, 7-, 14-, 21- і 28-му добу після травми. Контрольних тварин тільки вводили у наркоз.

У тварин, які вижили, стан ПОЛ оцінювали за вмістом у гомогенаті тканини міокарда ТБКактивних продуктів ПОЛ (ТБК-тіобарбітурова кислота) [9]. Рівень антиоксидантної системи визначали за активністю супероксиддисмутази (СОД) [10] і каталази [11]. Антиоксидантнопрооксидантний індекс (АПІ) розраховували за співвідношенням: активність каталази - вміст ТБК-активних продуктів ПОЛ [12]. Отримані цифррові дані обробляли статистично. Достовірність відмінностей між дослідними і контрольною групами оцінювали 3 використанням програми STATISTICA 10.0 (StatSoft, Inc., США).

Виклад основного матеріалу. Після модельованої скелетної травми, порівняно із контрольною групою, як видно 3 таблиці 1, вміст ТБК-активних продуктів ПОЛ у тканині міокарда був статистично достовірно більшим у всі терміни спостереження ( $<<0,001)$.

Через дві години він різко зростав і у 2,5 раза перевищував рівень контролю ( $<<0,001)$, через добу вміст ТБК-активних продуктів ПОЛ знижувався й був вірогідно меншим відносно попереднього терміну спостереження $(p<0,05)$, проте через три доби він знову підвищувався, досягаючи макисмального відхилення від контрольного рівня. В подальшому до 14-ї доби досліджуваний показник знижувався й досягав $174,3 \%$ контрольної гурпи. Через 28 діб відмічалося його наступне зменшення до рівня 140,2 \% контрольної групи.

Активність СОД тканини міокарда через дві години після нанесення травми мала тенденцію

ТАБЛИЦЯ 1 - Динаміка показників пероксидного окиснення ліпідів та антиоксидантного захисту у тканині міокарда у відповідь на скелетну травму $(\mathrm{M} \pm \mathrm{m})$

\begin{tabular}{|c|c|c|c|c|c|c|c|c|}
\hline \multirow{2}{*}{$\begin{array}{l}\text { Біомеханічний } \\
\text { показник }\end{array}$} & \multirow{2}{*}{$\begin{array}{c}\text { Контрольна } \\
\text { група } \\
(\mathrm{n}=20)\end{array}$} & \multicolumn{7}{|c|}{$\begin{array}{c}\text { Дослідна група } \\
\text { (показники через } 2 \text { години, на } 1 \text {-шу - 28-му добу після травми) }\end{array}$} \\
\hline & & $\begin{array}{l}2 \text { години } \\
(n=6)\end{array}$ & $\begin{array}{c}1 \\
(n=8)\end{array}$ & $\begin{array}{l}3 \\
(n=5)\end{array}$ & $\begin{array}{c}7 \\
(n=6)\end{array}$ & $\begin{array}{c}14 \\
(n=6)\end{array}$ & $\begin{array}{l}21 \\
(n=6)\end{array}$ & $\begin{array}{c}28 \\
(n=6)\end{array}$ \\
\hline $\begin{array}{l}\text { ТБК-активні продукти } \\
\text { ПОЛ, мкмоль } \cdot \Gamma^{-1}\end{array}$ & $\begin{array}{l}4,28 \pm \\
\pm 0,15\end{array}$ & $\begin{array}{l}10,79 \pm \\
\pm 0,16\end{array}$ & $\begin{array}{l}8,21 \pm \\
\pm 0,67\end{array}$ & $\begin{array}{l}10,94 \pm \\
\pm 0,43\end{array}$ & $\begin{array}{l}9,30 \pm \\
\pm 0,80\end{array}$ & $\begin{array}{l}7,46 \pm \\
\pm 0,22\end{array}$ & $\begin{array}{l}7,56 \pm \\
\pm 0,46 \\
\end{array}$ & $\begin{array}{r}6,00 \pm \\
\pm 0,19^{* * *+} \\
\end{array}$ \\
\hline СОД, \% & $\begin{array}{l}34,17 \pm \\
\pm 0,16 \\
\end{array}$ & $\begin{array}{l}39,20 \pm \\
\pm 1,73^{*} \\
\end{array}$ & $\begin{array}{c}34,91 \pm \\
\pm 1,18 \\
\end{array}$ & $\begin{array}{l}25,38 \pm \\
\pm 1,16\end{array}$ & $\begin{array}{l}26,83 \pm \\
\pm 1,27^{* *}\end{array}$ & $\begin{array}{l}55,90 \pm \\
\pm 2,74^{* *}\end{array}$ & $\begin{array}{c}34,74 \pm \\
\pm 1,90\end{array}$ & $\begin{array}{l}41,60 \pm \\
\pm 1,28^{*}\end{array}$ \\
\hline Каталаза,\% & $\begin{array}{c}25,56 \pm \\
\pm 2,28\end{array}$ & $\begin{array}{c}27,37 \pm \\
\pm 0,67\end{array}$ & $\begin{array}{c}22,98 \pm \\
\pm 1,19\end{array}$ & $\begin{array}{l}15,74 \pm \\
\pm 0,55^{* * *}\end{array}$ & $\begin{array}{l}20,92 \pm \\
\pm 1,23^{*}\end{array}$ & $\begin{array}{c}25,33 \pm \\
\pm 1,80\end{array}$ & $\begin{array}{c}21,72 \pm \\
\pm 1,06\end{array}$ & $\begin{array}{c}25,11 \pm \\
\pm 0,69\end{array}$ \\
\hline АП ${ }^{* * *}, \%$ & $\begin{array}{l}6,06 \pm \\
\pm 2,28\end{array}$ & $\begin{array}{l}2,54 \pm \\
\pm 0,04\end{array}$ & $\begin{array}{l}2,91 \pm \\
\pm 0,25\end{array}$ & $\begin{array}{l}1,44 \pm \\
\pm 0,03\end{array}$ & $\begin{array}{l}2,35 \pm \\
\pm 0,26\end{array}$ & $\begin{array}{l}3,43 \pm \\
\pm 0,30\end{array}$ & $\begin{array}{l}2,93 \pm \\
\pm 0,24\end{array}$ & $\begin{array}{l}4,20 \pm \\
\pm 0,18\end{array}$ \\
\hline
\end{tabular}

${ }^{*} \mathrm{p}<0,05 ;{ }^{* \star} \mathrm{p}<0,01 ;{ }^{* \star *} \mathrm{p}<0,001$ 
до зростання - на $14,7 \%$, порівняно 3 контрольною групою $(p<0,10)$. Через одну добу вона нормалізувалася, проте через 3-7 діб статистично достовірно знижувалася - в середньому на 23,7\% (p<0,01). Через 14 діб досліджуваний показник значно зростав і суттєво перевищував рівень контролю (на 63,6 \%, p $<0,01$ ). Через 21 і 28 діб настав повторний період зниження до рівня норми і наступного підвищення на 21,7 \% $(p<0,01)$.

Активність каталази тканини міокарда відносно контрольної групи впродовж двох годин і першої доби після травми істотно не змінювалася. Через три доби активність цього фрерменту значно знижувалася - на 38,4 \% (р < 0,001). Далі вона підвищувалася, через 14 діб нормалізувалася й залишалася на такому ж рівні до 28-ї доби.

Коливання величин вмісту вторинних продуктів ПОЛ та активності каталази тканини міокарда, порівняно із контрольною групою, зумовлювало значне зниження АПІ у всі терміни спостереження. Через три доби рівень цього показника досягав мінімальної величини $(23,8 \%$ контрольної групи), через 14 діб відмічався період його зростання до 56,6 \% контрольної групи. В подальшому до 28-ї доби показник змінювався у напрямку норми й становив всього 69,3\% контрольної групи.

Таким чином, в динаміці модельованої політравми у тканині міокарда, починаючи із першої години посттравматичного періоду, відмічається інтенсифрікація ПОЛ, що проявляється істотним зростанням вмісту ТБК-активних продуктів через три доби після нанесення травми 3 наступним зниженням, з сьомої доби.

Для активності СОД гомогенату міокарда типовим $€$ три періоди збільшення активності - перший через дві години, який, однак, не компенсує патогенних чинників ліпопероксидації, оскільки в

\section{Література}

1. АндрееВа Л. И. Модисрикация метода определения перекисей липидов в тесте с тиобарбитуровой кислотой / Л. И. Андреева, Л. А.Кожемякин, А. А. Кишкун // Лаб. дело. - 1988. - № 11. - С. 41-43.

2. Гембицкий $E$. В. Патология внутренних органов при травме / Е. В. Гембицкий, Л. М. Клячкин, М. М. Кириллов. М.: Медицина, 1994. - 256 с.

3. Генинг Т. П. Показатели перекисного окисления липидов и антиоксидантной защиты в системе «сыворотка крови - эритроцит» при острой циркуляторной гипоксии / Т. П. Генинг, Д. А. Ксейко // Успехи современного естествознания. - 2004. - № 4. - С. 17-20.

4. Гуманенко E. K. Достижения в лечении тяжелой сочетанной травмы за последние 20 лет / Е. К. Гуманенко, А. Б. Сингаевский // Скорая мед. помощь. - 2004. - Т. 5, № 3. - С. 153-154. цей термін інтенсивність ПОЛ в міокарді значно зростає; другий - через 14 діб, що відповідає протифразі зменшення вмісту ТБК-активних продуктів і вказує на залучення в цей період ендогенних саногенних механізмів (виснаження активності фрерментна настає через три доби - в період найбільшої активності ПОЛ); третій пік активності настає через 28 діб.

Динаміці активності каталази печінки характерним $\epsilon$ істотне зниження так само через три доби, що вказує на інтенсивне утворення в цей період гідрогену пероксиду, з наступною нормалізацією величини даного показника.

Інтегральним показником антиоксидантнопрооксидантного балансу $€$ АПІ. Його статистично достовірно низький рівень порівняно із контрольною групою вже через дві години і впродовж усього терміну спостереження з періодом значного зниження через три доби вказує на значну роль активних форм кисню в патогенезі ліпопероксидації на тлі тяжкої травми [13].

Таким чином, модельована травма супроводжується значною інтенсифікацією процесів ліпопероксидації у тканині міокарда та виснаженням ферментативної ланки антиоксидантного захисту, що створює умови для дистрофрічних змін та зниження фрункціональної здатності міокарда. Отримані результати $€$ теоретичним підгрунтям для застосування засобів кардіопротекції в умовах спортивної травами.

Висновки. У тканині міокарда під впливом скелетної травми вже через дві години істотно зростає, порівняно із контрольною групою, вміст ТБК-активних продуктів ПОЛ, який залишається підвищеним до 28-ї доби посттравматичного періоду. Найбільша інтенсифікація ліпопероксидації та виснаження антиоксидантного захисту настає через три доби після нанесення травми.

\section{References}

1. Andreyeva L. I. Modification of the method for determining the peroxide lipids in tests with thiobarbituric acid / L. I. Andreyeva, L. A. Kozhemyakyn, A. A. Kishkun // Lab. work. - 1988. - N. 11. - P. 41-43.

2. Hembytskyy Ye. V. Internal organs pathology by trauma / Ye. V. Hembytskyy, L. M. Klyachkin, M. M. Kirilov. Moscow: Medicina, 1994. - 256 p.

3. Hening T. P. Indicators of lipid peroxidation and antioxidant defence in the system «Serum - erythrocyte» by acute circulatory hypoxia / T. P. Hening, D. A. Kseyko // The success of modern science. - 2004. - N. 4 . P. 17-20.

4. Humanenko Ye. K. Achievements in the treatment of severe associated trauma over the past 20 years / Humanenko Ye. K., Singayevsky A. B. // Emergency Medical Aid. 2004. - Vol. 5, Nr. 3. - P. 153-154 . 
5. Ельский В. Н. Избранные аспекты патогенеза и лечения травматической болезни / [В. Н. Ельский, В. Г. Климовицкий, С. Е. Золотухин и др.]. - Донецк: ООО «Лебедь», 2002. -360 c.

6. Козак Д. В. Динаміка показників антиоксидантного захисту у відповідь на політравму / Д. В. Козак // Шпитальна хірургія. - 2012. - № 3. - С. 60-64.

7. Королюк M. A. Метод определения активности каталазы / М. А. Королюк, Л. И. Иванова, И. Г. Майорова, В. Е. Токарев // Лабораторное дело. - 1988. - № 1. C. $16-19$.

8. Левенець В. М. Актуальні питання спортивного травматизму / В. М. Левенець // Спорт. медицина. - 2004. № $1 / 2$. - С. 84-90.

9. ЛеВицкий А. П. Антиоксидантно-прооксидантний індекс сироватки крові щурів з експериментальним стоматитом і його корекція зубними еліксирами / А. П. Левицький, В. М. Почтар, О. А. Макаренко, Л.І.Гридіна // Одеський мед. журн. - 2006. - № 1. - С. 22-25.

10. Петухова О. В. Содержание липопротеидов и продуктов перекисного окисления липидов у больных в остром периоде политравмы / О.В.Петухова, И.М.Устьянцева, В В. Агаджанян // Политравма. - 2006. - № 3. - С. 65-68.

11. Платонов В. Н. Травматизм в спорте: проблемы и перспективы их решения / В. Н. Платонов //Спорт. медицина. - 2006. - № 1. - С. 54-77.

12. ЧеВари С. Роль супероксиддисмутазы в окислительных процессах клетки и метод определения ее в биологических материалах / С. Чевари, И. Чаба, Й. Сокей / / Лаб. дело. - 1985. - N 11. - С. 678-681.

13. Sharma S. Physiologic limits of left ventricular hypertrophy in elite junior athletes: relevance to differential diagnosis of athlete's heart and hypertrophic cardiomyopathy / [S. Sharma, B. J. Maron, G. Whyte et al.] // J. Am Coll Cardiol. - 2002. - Vol. 40. - P. 1431-1436.
5. Yelsky V. N. Popular aspects of pathogenesis and treatment of traumatic sicease / V. N. Yelsky, V. H. Klimovitsky, S. Ye. Zolotukin [et al.] - Donetsk: LLC «Lyebed», 2002. -360 p.

6. Kozak D. V. The evolution of the antioxidant defence in response to polytrauma / D. V. Kozak // Hospital Surgery. -2012 . - N. 3. - P. 60-64.

7. Korolyuk M. A. Method for determination of catalase activity / M. A. Korolyuk, L. I. Ivanova, I. H. Mayorova, V. Ye. Tokaryev // Lab. work. - 1988. - N. 1. P. 16-19.

8. Levenets V. M. Actual questions of sports traumatism / V. M. Levenets // Sports Medicine. - 2004. - N. 1/2. P. 84-90.

9. Levytskyy A. P. Antioxidant and prooxidant index of rats serum with experimental stomatitis and its correction with mouthwash / A. P. Levytskyy, V. M. Pochtar, O. A. Makarenko, L. I. Hrydina // Odessa Medical jornal. - 2006. N 1. - P. 22-25.

10. Petukhova O. V. Lipoproteins and lipid peroxidation by patients with acute polytrauma / O. V. Petukhova, I. M. Ustyantseva, V. V. Ahadzhanyan // Polytrauma. 2006. - N. 3. - P. 65-68.

11. Platonov V. N. Injuries in Sport: Problems and prospects of their solutions / V. N. Platonov // Sports Medicine. -2006 . - N. 1. - P. 54-77.

12. Chevary S. Role of superoxidedismutase in cells oxidative processes and its determination method in biological materials / S. Chevary, I. Chaba, Yo. Sokey // Lab. work. 1985. - N. 11. - P. 678-681.

13. Sharma S. Physiologic limits of left ventricula rhypertrophy in elite junior athletes: relevance to differential diagnosis of athlete's heart and hypertrophic cardiomyopathy / [S.Sharma, Maron B. J., Whyte G. et al.] // J. Am. Coll. Cardiol. - 2002. - Vol. 40. - P. 1431-1436. 